\title{
Credit counseling: a substitute for consumer financial literacy?
}

\author{
RICHARD DISNEY \\ Department of Economics, University College, London; Institute for Fiscal Studies, London; \\ University of Sussex, Brighton; UK \\ (e-mail: richard_deifs.org.uk)
}

\section{JOHN GATHERGOOD}

School of Economics, University of Nottingham, Network for Integrated Behavioural Science, Nottingham, UK

\section{JÖRG WEBER}

School of Economics, University of Nottingham, Network for Integrated Behavioural Science, Centre for Decision Research and Experimental Economics, Nottingham, UK

\begin{abstract}
Is financial literacy a substitute or complement for financial advice? We analyze the decision by consumers to seek financial advice in the form of credit counseling. Credit counseling is an important component of the consumer credit sector for consumers facing debt problems. Our analysis accounts for the endogeneity of an individual's financial situation to financial literacy, and the endogeneity of financial literacy to exposure to credit counseling. Results show counseling substitutes for financial literacy. Individuals with better literacy are $60 \%$ less likely to use credit counseling. These results suggest that credit counseling provides a safety net for poor financial literacy.
\end{abstract}

JEL CODES: D10, D12, I22

Keywords: Credit counseling, financial advice, financial literacy, household finance.

\section{Introduction}

This paper estimates the impact of financial literacy on the demand for financial advice, specifically the demand for professional 'credit counseling' among consumers facing financial problems. Credit counseling services offer advice to consumers regarding their credit and debt and are commonly used by individuals with problem debt, such as late payments on a credit card. The consequences of poor financial literacy might be less severe if consumers can turn to the assistance of a credit counselor when faced with a financial problem or challenge. We focus on credit counseling as consumers with debt problems typically exhibit low levels of income and wealth and low levels of financial literacy, so the marginal utility of advice is likely to be 
high for this group compared with wealthier households. We show that, for a given debt problem, a one-unit increase in financial literacy on our four-point index decreases the likelihood of an individual seeking help and assistance from a credit counselor by approximately $60 \%$. Our results support the view that credit counseling is a substitute, and maybe acts as a safety net, for poor financial literacy.

Our focus on the relationship between financial literacy and financial advice in the form of credit counseling differs from the previous literature which has focused on financial advice provided by investment advisors. A number of studies show that financial literacy and the advice of professional investment advisors are typically complements (Hackethal et al., 2012; Bucher-Koenen and Koenen, 2015). Recently, Calcagno and Monticone (2015) have shown that, among a sample of Italian investors, those with poor literacy are less likely to seek investment advice. Collins (2012) shows that investors with low levels of financial literacy are more likely to invest without seeking advice. Willis (2011) discusses the role of financial education as a substitute for financial advice.

To our knowledge, the interplay between financial literacy and financial advice in the specific form of credit counseling has not been investigated in much of the prior literature. Two prior studies consider the interplay between low financial literacy and financial services. Bernheim (1995) shows that many workers are unaware of their financial illiteracy, suggesting they may not realize the need for financial advice. Cole et al. (2011) show individuals with better financial literacy are more likely to choose basic financial services, such as bank accounts. Two other recent studies analyze the relationship between financial literacy and the effects of financial advice in the mortgage market. Moulton et al. (2013) argue that first-time home-buyers who underestimate or overestimate their total debt or misunderstand monthly debt payments are more likely to seek financial counseling. Agarwal et al. (2014) find that financial counseling has no direct effect on mortgage choices, but an indirect effect occurs via mandatory counseling discouraging low credit score borrowers from applying for risky mortgages.

Other prior studies have shown that financial literacy is important for savings behavior (Bernheim, 1995, 1998; Lusardi and Mitchell, 2007, 2011; Chan and Stevens, 2008; Behrman et al., 2012), investment and portfolio decisions (Christelis et al., 2010; van Rooij et al., 2011; Yoong, 2011) and choices in the credit market (Lusardi and Tufano, 2009; Disney and Gathergood, 2013; Gerardi et al., 2013). In addition, existing studies show that financial literacy arises in part due to institutional features, such as public provision of saving vehicles, but also familial background and upbringing and education (Jappelli, 2010; Carpena et al., 2011). For a recent review of the financial literacy literature see Lusardi and Mitchell (2014).

Financial literacy is seen as key to financial decision making and financial independence. Is financial literacy, therefore, a substitute or a complement for credit counseling? If an individual's financial literacy removes the need to seek advice about their credit and debt from others in financial decisions, then financial literacy could be a substitute for professional advice, which in many settings is available only at some cost, including the time cost of liaising with an advisor. Alternatively, if credit counseling is readily available at low cost, consumers might choose not to invest in learning and use advice as a cheaper substitute. In both scenarios, financial advice and financial literacy are substitutes. 
However, there may be reasons why financial literacy and credit counseling act as complements. Financial literacy might be important for the realization that counseling advice is required. It might also be necessary in order to benefit from counseling and to put advice into practice. As such, financial literacy may be a complement to credit counseling. The potential for both substitution and complementarity between financial literacy and credit counseling is the key issue we address in this paper.

The context we focus on is that of 'credit counseling' in the consumer credit market. Credit counseling is a form of financial advice on credit and debt typically used by individuals facing over-indebtedness or problems relating to credit and debt repayment. Credit counseling typically occurs via an interview with a client about their financial situation which leads to some advice or an intervention provided by the credit counseling agency. These may include negotiations with creditors, re-organization of client budgets and repayment plans and potentially assistance with bankruptcy filings. In the UK, credit counseling is normally available for free from charities and/or government providers and the most British users of credit counseling make use of free-to-client advice providers. There is a large credit counseling sector in the US and UK comprising charitable and fee charging advice providers. Staten (2006) estimates that 5-6 million US individuals use a credit counseling advisor each year. For the UK, the Money Advice Service (2013) estimates 2 million UK individuals seek advice from an advice provider. Nearly all credit counseling occurs via the telephone or via the internet in the UK.

This context of consumer debt is particularly appropriate for analyzing whether financial advice can act as a 'safety net' for those with poor financial literacy. Individuals with credit and debt repayment problems typically show poor financial literacy (Gathergood, 2012). Evidence on the effectiveness of credit counseling should focus not just on the self-selection of individuals into credit counseling by their financial existing situation (as in Xiao et al., 2006; Elliehausen et al., 2007; Nurcan and Bièáková, 2010), but also by their individual financial capabilities. This latter question lies at the heart of the present paper and we now turn to the methodology we use to identify the relationship between financial literacy and credit counseling.

\section{Methodology}

We use a unique survey dataset from the UK into which we inserted survey questions on financial literacy and other behavioral characteristics of consumers. Our dataset comprises survey data for approximately 1,300 UK individuals with financial problems, drawn from a subset of the YouGov Debt Tracker survey and collected in October 2010. The Debt Tracker is a representative cross-sectional survey of approximately 3,000 UK individuals conducted on a quarterly basis since the year 2000. The survey asks individuals about their financial situation and the extent to which they face debt problems on a self-reported scale. Individuals who state they sometimes 'struggle' with their financial commitments then receive an additional series of questions on what steps they have taken to address their financial commitments, including use of credit counseling. This sample forms the analysis sample in our paper.

Our empirical approach is based on a dual strategy to address first the endogeneity of an individual's debt problems to financial literacy, and second the endogeneity of 
financial literacy to exposure to credit counseling. In our data we observe an individual's financial literacy as measured using survey questions, an individual's self-reported financial situation and information on whether an individual has sought professional credit counseling within the last 6 months. The first component of our empirical strategy is a Heckman selection correction model to address the endogeneity of an individual's debt problems to his or her financial literacy. Our interest is in how financial literacy affects the decision to seek credit counseling when facing financial difficulty. However, financial difficulty itself may be due to poor financial literacy. A negative relationship between financial literacy and credit counseling could arise because individuals with better financial literacy are less likely to face debt problems, and hence have less need for credit counseling.

We address this endogeneity problem by instrumenting selection into having a 'debt problem' using a series of variables which capture exogenous shocks to the individual's financial circumstance unrelated to financial literacy. The shocks we exploit are employment shocks, income shocks and health shocks. These are arguably exogenous to an individual's financial literacy but, as we show, predict the likelihood of an individual facing a debt problem. Therefore, our results on the relationship between financial literacy and credit counseling are estimated using exogenous variation arising due to shocks.

Second, we instrument financial literacy which may arise endogenously with receipt of credit counseling. Our interest is in how financial literacy affects the decision to seek credit counseling, but in our data observed financial literacy at the time of the survey could arise due to the effects of credit counseling received previously. Credit counseling often takes the form of advice relating to remedial actions for the client's finances, but also often includes the offer of financial education opportunities. This may create a reverse causation channel in our data.

We therefore adopt instrumental variables (IV) approach and instrument current financial literacy using the extent of economics- and finance education in school. We combine this IV strategy with the Heckman selection model to create a two-step estimation procedure which employs the selectivity correction adjustment and IV method to account for these two forms of endogeneity simultaneously. We show results with and without the two instrumental variable methods.

Our key finding is that, for a given debt problem, financial literacy reduces the likelihood that an individual seeks credit counseling. A one unit increase in financial literacy, which in our analysis means answering an additional financial literacy question correctly, reduces the likelihood of an individual seeking credit counseling by approximately $60 \%$. This finding occurs in our baseline specification without instruments, in a specification including the Heckman selectivity correction and in a hybrid model that incorporates the selectivity correction adjustment into an IV model in which financial literacy is instrumented by early life financial education. We conduct further robustness analysis to show this finding is not sensitive to the choice of shock variables we include in the selection equation or alternative definitions of 'debt problem' used in the selectivity correction model.

The remainder of the paper is structured as follows: in the next section we describe the survey dataset, including the questions relating to financial literacy which we commissioned within the survey. This section also presents summary statistics for 
our data. Following that, the next section presents the econometric models. The penultimate section presents sensitivity analysis ahead of the conclusion.

\section{Data and summary statistics}

\subsection{Survey summary}

Our data drawn from the YouGov Debt Tracker survey focuses on consumer credit and debt, including topics such as consumer debt product holdings, credit applications and repayment behavior and difficulties. The survey is conducted via the internet once per quarter and takes approximately $40 \mathrm{~min}$ to complete. Individuals are paid approximately $£ 10$ for participation. The survey sample is a representative crosssection of the UK population. YouGov makes internet access available to households without access to the internet at home in order to achieve a representative sample.

We now describe the construction of our 'debt problem' measure from the survey and how it relates to the survey data design.

All respondents are asked early-on in the survey:

- 'Which one of the following statements best describes how well you (and your partner) are keeping up with your bills and credit commitments at the moment?'

Respondents select one option from six categories:

(1) I am/we are keeping up with all bills and commitments without any difficulties;

(2) I am/we are keeping up with all bills and commitments, but it is a struggle from time to time;

(3) I am/we are keeping all bills and commitments, but it is a constant struggle;

(4) I am/we are falling behind with some bills or credit commitments;

(5) I am/we are having real financial problems and have fallen behind with many bills or credit commitments;

(6) I/we do not have any bills or credit commitments.

Individuals who choose an answer (2-5) from the above list are identified as being at risk of debt problems and are then asked further questions about their bills and credit commitments, including details of problems repaying their debts and use of professional credit counseling advice. Individuals who answer (1) or (6) are not asked these questions, and their use of professional credit counseling advice is not observed. The dataset we use comprises 1,268 observations for individual respondents who answered (2-5).

All individuals in our sample are presented with a series of financial literacy questions. These questions are based upon those constructed by Lusardi and Tufano (2009). We have used them elsewhere in Gathergood (2012), Disney and Gathergood (2013) and Gathergood and Weber (2014). The questions are designed to test the respondent's understanding of simple interest, compound interest and (non-)amortization. The questions are framed in the context of consumer credit debt which is relevant for our interest in credit counseling in particular.

The three financial literacy questions are: 
1. 'Cheryl owes $£ 1,000$ on her bank overdraft and the interest rate she is charged is $15 \%$ per year. If she did not pay anything off, at this interest rate, how much money would she owe on her overdraft after 1 year?'

$-£ 850$

$-£ 1,000$

$-£ 1,150$

$-£ 1,500$

- Do not know

2. 'Sarah owes $£ 1,000$ on her credit card and the interest rate she is charged is $20 \%$ per year compounded annually. If she did not pay anything off, at this interest rate, how many years would it take for the amount she owes to double?'

- Less than 5 years

- Between 5 and 10 years

- More than 10 years

- Do not know

3. 'David has a credit card debt of $£ 3,000$ at an annual percentage rate of $12 \%$ (or $1 \%$ per month). He makes payments of $£ 30$ per month and does not gain any charges or additional spending on the card. How long will it take him to pay off this debt?'

- Less than 5 years

- Between 5 and 10 years

- More than 10 years

- None of the above, he will continue to be in debt

- Do not know

From respondents' answers to these three questions we create a financial literacy 'score' taking a value of $0-3$ (the mean value is 1.75 ).

In addition to these questions, all respondents are asked about their financial education while in full-time education which we later use as an instrument for current financial literacy:

- 'When you were in full time education (school, college or university) how much of your education was devoted to finance, economics and business?'

- A lot

- Some

- A little

- Hardly at all

From answers to this question we create the variable 'Financial education in school', which is coded from 1 ('Hardly at all') to 4 ('A lot').

All respondents are also asked about their use of credit counseling. The question asked is:

- 'Have you contacted anyone in the last 6 months to seek professional advice to help sort out any debt problems?' 
to which respondents answer 'yes' or 'no'. We use this binary indicator as our main outcome variable for whether an individual has sought credit counseling.

The question itself does not uniquely identify credit counseling providers, but in answers to a follow-up question on where the individual sought advice, $74 \%$ of respondents state the name of a credit counseling provider and a further $10 \%$ state they sought advice from their bank or credit provider. In such cases UK banks and credit providers routinely refer-on individuals to a credit counseling provider. Hence, we are confident that, in the large majority of cases, answers to this question identify seeking advice from a credit counselor. In all cases, individuals naming a credit counselor cited an organization or agency providing online or telephone counseling services.

In addition to these questions the survey includes a range of questions covering the individual's demographic and socio-economic characteristics including age, gender, marital status, children within the household, educational background, income and employment. The survey also includes a series of questions on 'shocks' the household faced within the previous 6 months. We describe additional questions we use as instruments later in the results sections.

\subsection{Summary statistics}

Summary sample statistics for our analysis are provided in the first column of Table 1. The sample of 1,268 households comprises those among a representative sample of the UK population who report they struggle to meet their bills and credit commitments at least 'occasionally'. Our sample comprises mostly working age respondents, the majority of whom are married and one-third of whom have dependent children. Nearly three quarters of respondents are employed and close to half has a spouse or partner who is also employed. Approximately half of respondents are home owners with mortgage debt.

Average household income is close to the UK average at $£ 33,000$ with individuals on average holding approximately $£ 3,500$ in liquid savings and consumer credit debt plus mortgage debt of approximately $£ 26,000$. When we compare our sample with a representative sample of UK households in the 'Wealth and Assets Survey', we see that respondents in our survey are typically younger, have higher income, are more likely to have children and are more likely to be in employment. This is as expected as theory suggests young to middle aged households are likely to hold the highest level of secured and unsecured debts.

Column 2 splits the analysis sample into two mutually exclusive and exhaustive groups by whether they recently sought credit counseling. Approximately $15 \%$ of the analysis sample had sought counseling within the previous 6 months. Those seeking credit counseling show very similar demographic characteristics in age, gender, marital status and dependent children to those not seeking counseling. They are slightly less likely to be employed or have a partner or spouse in employment. Those seeking counseling are more likely to be private renters or social renters. 
Table 1. Sample characteristics

\begin{tabular}{|c|c|c|c|c|c|}
\hline & \multirow[t]{2}{*}{ (1) } & \multicolumn{2}{|c|}{ (2) } & \multicolumn{2}{|c|}{ (3) } \\
\hline & & \multicolumn{2}{|c|}{ Credit counseling } & \multicolumn{2}{|c|}{ Debt problems } \\
\hline & Sample & No & Yes & No & Yes \\
\hline \multicolumn{6}{|l|}{ Age } \\
\hline $18-24$ & 0.07 & 0.08 & 0.02 & 0.07 & 0.06 \\
\hline $25-34$ & 0.24 & 0.24 & 0.23 & 0.24 & 0.24 \\
\hline $35-44$ & 0.24 & 0.25 & 0.24 & 0.24 & 0.24 \\
\hline $45-54$ & 0.23 & 0.23 & 0.27 & 0.22 & 0.25 \\
\hline $55+$ & 0.21 & 0.21 & 0.24 & 0.22 & 0.20 \\
\hline \multicolumn{6}{|l|}{ Demographics } \\
\hline Male (=1) & 0.44 & 0.43 & 0.45 & 0.45 & 0.41 \\
\hline Married/living as married $(=1)$ & 0.64 & 0.65 & 0.60 & 0.67 & 0.59 \\
\hline Divorced $(=1)$ & 0.07 & 0.07 & 0.06 & 0.06 & 0.07 \\
\hline Dependent children $(=1)$ & 0.29 & 0.28 & 0.30 & 0.27 & 0.31 \\
\hline Financial education in school $(1-4)$ & 1.44 & 1.45 & 1.37 & 1.47 & 1.40 \\
\hline \multicolumn{6}{|l|}{ Employment } \\
\hline Employed (=1) & 0.72 & 0.72 & 0.69 & 0.76 & 0.63 \\
\hline Unemployed (=1) & 0.06 & 0.06 & 0.07 & 0.05 & 0.08 \\
\hline Retired/student/housewife/disabled & 0.23 & 0.22 & 0.24 & 0.19 & 0.29 \\
\hline Spouse employed $(=1)$ & 0.49 & 0.49 & 0.44 & 0.52 & 0.42 \\
\hline \multicolumn{6}{|l|}{ Housing } \\
\hline Homeowner without mortgage $(=1)$ & 0.14 & 0.15 & 0.05 & 0.16 & 0.10 \\
\hline Homeowner with mortgage $(=1)$ & 0.47 & 0.48 & 0.39 & 0.50 & 0.40 \\
\hline Private renter $(=1)$ & 0.22 & 0.20 & 0.30 & 0.20 & 0.25 \\
\hline Social renter including rent-free $(=1)$ & 0.18 & 0.17 & 0.27 & 0.14 & 0.25 \\
\hline
\end{tabular}


Table 1 (cont.)

\begin{tabular}{|c|c|c|c|c|c|}
\hline & \multirow[t]{2}{*}{ (1) } & \multicolumn{2}{|c|}{ (2) } & \multicolumn{2}{|c|}{ (3) } \\
\hline & & \multicolumn{2}{|c|}{ Credit counseling } & \multicolumn{2}{|c|}{ Debt problems } \\
\hline & Sample & No & Yes & No & Yes \\
\hline \multicolumn{6}{|l|}{ Household finances } \\
\hline Household income $(£)$ & $33,200(30,000)$ & $33,800(30,000)$ & $29,600(25,000)$ & $35,900(33,000)$ & $28,500(25,000)$ \\
\hline Liquid savings (£) & $3,500(0)$ & $3,800(0)$ & $1,500(0)$ & $4,700(100)$ & $1,300(0)$ \\
\hline Consumer credit debt $(£)$ & $3,400(0)$ & $3,000(0)$ & $6,200(900)$ & $2,700(0)$ & $4,700(500)$ \\
\hline Secured credit $(£)$ & $25,700(0)$ & $25,600(0)$ & $26,200(0)$ & $27,500(0)$ & $22,300(0)$ \\
\hline Observations & 1,268 & 1,106 & 162 & 819 & 449 \\
\hline
\end{tabular}

Note: Column 1 shows summary statistics for the whole sample of respondents. Column 2 separates the sample into two mutually exclusive groups by whether the respondent had sought professional credit counseling advice about their debt problems within the last 6 months. Column 3 separates the sample into two mutually exclusive groups by whether the respondent self-reports that they currently have a debt problem (see main text for definition of 'debt problems').

Mean values are reported with median values shown in parentheses for financial variables.

Source: YouGov Debt Tracker, October 2010. 
They have lower incomes, less savings and approximately twice the consumer credit debt of those not seeking counseling.

Column 3 provides further summary statistics by whether the individual has a 'debt problem'. An individual is classed as being in the 'debt problem' group if they struggle to meet their bills and credit commitments more frequently (answers 3, 4 and 5 of the question how respondents keep up with their financial obligations). Hence individuals who report they struggle to meet their bills and credit commitments only 'from time to time' (answer 2) comprises the 'no' group shown in the table. Summary statistics for the mutually exclusive and exhaustive groups show that the two groups are similar in age. Those with debt problems are slightly more likely to be female, less likely to be married, less likely employed and more likely to be a private renter or social renter. They receive on average less income, hold lower savings with more consumer credit debt.

Table 2 provides summary data for responses to the financial literacy questions. We show the three financial literacy questions which form the basis of our financial literacy score together with a breakdown of responses among each of the groups shown in Table 1 . Overall $84 \%$ of individuals answer the first 'simple interest' question correctly; $52 \%$ answer the compound interest question correctly and $42 \%$ answer the minimum payments question correctly. In the whole sample the average literacy score is 1.75. The average literacy score is lower for those with debt problems (1.66 for those with debt problems compared with 1.81 for those without debt problems) and also lower for those seeking credit counseling (1.45 for those seeking counseling compared with 1.80 for those not seeking counseling).

On the basis of these summary data it is perhaps unsurprising that those seeking credit counseling have, on average, lower financial literacy because credit counseling correlates with debt problems. Table 3 shows this correlation by tabulating the credit counseling dummy variable against categorical answers to the question used to identify debt problems. Among the 819 individuals reporting they 'struggle from time to time' only $45(5.5 \%)$ seek credit counseling, whereas among the 54 individuals with 'real financial problems' $32(60 \%)$ seek credit counseling.

Our definition of the relevant 'debt problem' group is subject to judgment. Our baseline definition comprises those answering 3, 4 or 5 to the question given in Table 3, among which 117 out of 449 (26\%) seek credit counseling. Later in our sensitivity analysis we also employ a narrower definition of 'debt problem' which captures only respondents who state they are 'falling behind with commitments or have 'real financial problems' (answers 4 and 5). This group includes 118 individuals, $26 \%$ of the wider definition debt problem group. These summary data, therefore, show a similar pattern in differences between those who do and do not seek credit counseling and those who do and do not have debt problems.

Later, we also use another alternative measure of problem debt based on whether the individual reports their financial situation is worse than 12 months ago. A specific survey question asks respondents to describe their financial position compared with a year ago. Among five possible answers the 'worst' is: 'I/we were in financial difficulties 12 months ago and things are now even worse'. We use this as an alternative definition of (potentially more severe) problem debt. $32 \%$ of those in the debt problem group answer 'yes' to this question as do $29 \%$ of those seeking credit counseling. 
Table 2. Financial literacy performance

\begin{tabular}{ccccc}
\hline \hline & $(1)$ & $(2)$ & & $(3)$ \\
\cline { 2 - 5 } & & $\begin{array}{c}\text { Credit } \\
\text { counseling }\end{array}$ & & $\begin{array}{c}\text { Debt } \\
\text { problems }\end{array}$ \\
\cline { 3 - 5 } & Sample & No $\quad$ Yes & No Yes \\
\hline
\end{tabular}

1. 'Cheryl owes $£ 1,000$ on her bank overdraft and the interest rate she is charged is $15 \%$ per year. If she did not pay anything off, at this interest rate, how much money would she owe on her overdraft after one year?'

$\begin{array}{llllll}£ 850 & 0.01 & 0.01 & 0.01 & 0.01 & 0.02 \\ £ 1,000 & 0.00 & 0.00 & 0.02 & 0.00 & 0.01 \\ £ 1,150 & 0.84 & 0.85 & 0.79 & 0.87 & 0.80 \\ £ 1,500 & 0.08 & 0.08 & 0.09 & 0.08 & 0.09 \\ \text { Do not know } & 0.06 & 0.06 & 0.09 & 0.05 & 0.08\end{array}$

2. 'Sarah owes $£ 1,000$ on her credit card and the interest rate she is charged is $20 \%$ per year compounded annually. If she did not pay anything off, at this interest rate, how many years would it take for the amount she owes to double?'
Less than 5 years
0.52
0.54
0.43
0.56
0.46
Between 5 and 10 years
0.28
0.28
0.30
$\begin{array}{ll}0.28 & 0.29\end{array}$
More than 10 years
0.06
0.05
0.08
$\begin{array}{ll}0.04 & 0.08\end{array}$
Do not know
0.14
0.13
0.19
$\begin{array}{ll}0.12 & 0.17\end{array}$

3. 'David has a credit card debt of $£ 3,000$ at an annual percentage rate of $12 \%$ (or $1 \%$ per month). He makes payments of $£ 30$ per month and does not gain any charges or additional spending on the card. How long will it take him to pay off this debt?'

\begin{tabular}{lccccc} 
Less than 5 years & 0.05 & 0.04 & 0.07 & 0.03 & 0.07 \\
Between 5 and 10 years & 0.15 & 0.15 & 0.19 & 0.14 & 0.18 \\
More than 10 years & 0.18 & 0.18 & 0.20 & 0.19 & 0.17 \\
None of the above, he will continue to be in debt & 0.42 & 0.43 & 0.33 & 0.45 & 0.37 \\
Do not know & 0.20 & 0.20 & 0.20 & 0.19 & 0.21 \\
\hline Literacy score (0-4) & 1.75 & 1.80 & 1.45 & 1.81 & 1.66 \\
\hline Observations & 1,268 & 1,106 & 162 & 819 & 449 \\
\hline
\end{tabular}

Note: Table shows breakdown of answers to financial literacy questions. Column 1 shows statistics for those individuals who sought credit counseling within the last 6 months. Column 2 shows statistics respondents who self-report that they currently have a debt problem. Literacy score is the sum of financial literacy questions answered correctly (see main text for details). Italics denote correct answers.

Source: YouGov Debt Tracker, October 2010.

Summary data for these three definitions of debt problems we use in the analysis are shown in Table 4. Our baseline measure of debt problems is the broadest measure, capturing $35 \%$ of the sample, the narrower definition captures $9 \%$ of the sample and the definition based on worsening financial situation captures $14 \%$ of the sample.

In this table, we also provide summary data for the three household level shocks which we use as instruments in our selection model for debt problem to capture exogenous sources of debt problems unrelated to financial literacy. These are: whether the individual experienced an employment shock, income shock or health shock 
Table 3. Debt problem characteristics by whether respondent sought credit counseling

\begin{tabular}{lccr}
\hline \hline & \multicolumn{2}{c}{ Credit counseling } & \\
\cline { 2 - 3 } & No & Yes & Total \\
\hline 'Which one of the following statements best describes how & well you (and your partner) are \\
keeping up with your bills and credit commitments at the moment?' & & \\
Answer (2) struggle from time to time & 774 & 45 & 819 \\
Answer (3) constant struggle with commitments & 267 & 64 & 331 \\
Answer (4) falling behind with commitments & 43 & 21 & 64 \\
Answer (5) real financial problems & 22 & 32 & 54 \\
\hline Total & 1,106 & 162 & 1,268 \\
\hline \hline
\end{tabular}

Note: Table shows the number of individuals seeking credit counseling by answers to the multiple-choice question 'how are you keeping up with your bills and credit commitments these days'. We define the 'debt problems' group as individuals answering 3, 4 or 5. Our narrower definition of 'debt problems' is defined as individuals answering 4 or 5 .

Source: YouGov Debt Tracker, October 2010.

Table 4. Financial behavioral characteristics and household shocks

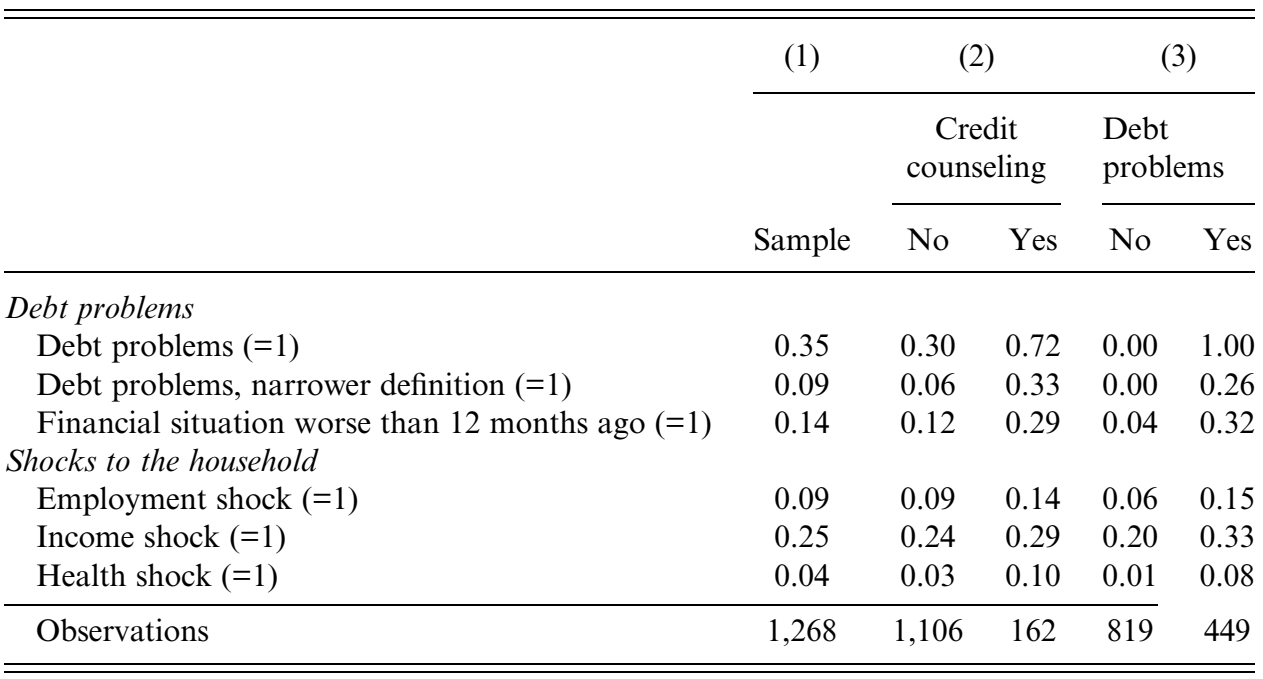

Mean values reported.

Source: YouGov Debt Tracker, October 2010.

within the previous 6 months. We argue below that these shocks are causes of debt problems but are unrelated to financial literacy. Among our whole sample $9 \%$ of respondents had experienced an employment shock, $25 \%$ an income shock and $4 \%$ a health shock. The high rates of suffering an income shock are unsurprising as our sample period occurs during a recession in the UK economy. Summary data show rates of experiencing each shock are higher among individuals in the problem debt group compared with those without problem debt. 
We later use these shocks as instruments in the selection model for the debt problem group. In doing so, we assume that each of the shocks is unrelated to financial literacy. The prior literature has shown that financial literacy is important for a range of household outcomes, including long-term saving, portfolio allocation and consumer credit and debt decisions. While financial literacy correlates with human capital and hence labor market status and the level of income we consider it to be less plausible that financial literacy is related to shocks to these. Similarly, we do not expect that financial literacy is related to the likelihood of an individual receiving a shock to their health.

However, to test whether this is the case, we show estimates from an ordered probit model in the appendix (Table A1) in which the dependent variable is our financial literacy index and the set of independent variables includes our three shock variables together with a rich set of socio-economic controls. Results show that none of the coefficients on the shock variables are statistically significant and hence indicate no causality between experiencing an employment, income or health shock and an individual's financial literacy. On this basis we judge these shocks to be suitable exclusion restrictions for our selectivity correction which identifies exogenous causes of debt problems arising independently of financial literacy.

\section{Empirical strategy and econometric results}

We now formally present our empirical strategy. Our interest is in understanding how financial literacy affects the decision to seek credit counseling. Summary statistics indicate that individuals seeking credit counseling typically have both debt problems and lower literacy. Hence, in order to estimate the impact of financial literacy on credit counseling, an empirical approach needs to be adopted which accounts for this potential selection bias. A randomized control trial in which a group of individuals with varying levels of financial literacy are randomly assigned debt problems is not possible.

We use a dual estimation strategy to address endogeneity concerns. The first part addresses the endogeneity of an individual's debt problem to financial literacy, exploiting exogenous variation in the likelihood of a debt problem unrelated to financial literacy. We use a Heckman selectivity correction model with a selection equation for the debt problem indicator variable, which uses recent shocks experienced by the household as instruments. These shocks are measured by the dummy variables for employment shock, income shock and health shock described in Table 4. These shocks affect the likelihood that an individual faces a debt problem, but are assumed independent of the individual's financial literacy.

The probit model for credit counseling with sample correction for the likelihood can be written as:

$$
\begin{gathered}
\text { credit counseling }=1\left[\beta_{0}+\beta_{1} F L+\mathbf{X}^{\prime} \beta+u>0\right], \\
\text { debt problem }=1\left[\beta_{0}+\beta_{1} F L+\mathbf{S}^{\prime} \delta+\mathbf{X}^{\prime} \omega+v>0\right],
\end{gathered}
$$

where (2) is the sample selection equation and the binary outcome variable credit counseling is only observed when debt problem $=1 . F L$ is the continuous measure of financial literacy, $\mathbf{S}^{\prime}$ a vector of the three exogenous shocks and $\mathbf{X}^{\prime}$ a vector of 
demographic and financial control variables. The two equations are jointly estimated using maximum likelihood. We report average marginal effects throughout the paper.

Table 5 column 1 shows results from a baseline probit model without the selectivity correction (equation 1) as well as the selectivity correction model in Columns 2 and 3 (equations 1 and 2). In column 1, the dependent variable is the $1 / 0$ dummy variable for whether the individual has sought credit counseling. The model includes covariates in age, gender, marital status, dependent children, employment, housing and household finances. Coefficient estimates for covariates show the likelihood of seeking credit counseling is decreasing in homeownership and household income and increasing in age and consumer credit debt.

The coefficient on the literacy score variable is negative and statistically significant at the $0.1 \%$ level of confidence. The average marginal effect takes a value of -0.043 , implying a one point increase in the literacy score is associated with a $4.3 \%$ point reduction in the likelihood of seeking credit counseling. The baseline predicted probability from the model is $12.8 \%$, so the $4.3 \%$ point reduction is a $34 \%$ reduction in the likelihood. This baseline estimate takes no account of the selection correction described earlier.

Estimates from the selection correction model are shown in Columns 2 and 3, where the employment shock, income shock and health shock dummies are used as instruments in the first-stage equation which predicts the likelihood of individuals having a 'debt problem'. The income and health shock dummies are both statistically significant at the $1 \%$ level or lower. The marginal effects imply that experience of an income shock raises the likelihood of debt problem by $10 \%$ points and experience of a health shock raises the likelihood by $32 \%$ points. The baseline predicted probability of a debt problem from the selection equation is $35 \%$, hence the marginal effects of the instruments are statistically large.

The second-stage regression is shown in Column 3. The Wald test of independence rejects the null of non-independence of equations at a 3\% level of confidence. In this model, the coefficient on the financial literacy score is negative and statistically significant at the $1 \%$ level. The value of the averaged marginal effect is -0.065 , implying a one point increase in the literacy score lowers the likelihood of an individual seeking credit counseling by $6.5 \%$ points. Against the baseline predicted probability of $21.1 \%$ this equates to a $31 \%$ decrease in the likelihood of seeking credit counseling.

These estimates suggest financial literacy has a large negative effect on the likelihood of seeking credit counseling and also suggest substitution between financial literacy and credit counseling. These results show that, accounting for exogenous selection into a debt problem, financial literacy reduces use of credit counseling.

However, while this addresses the endogeneity of an individual's financial situation to financial literacy, the possible endogeneity of financial literacy to exposure to credit counseling remains a confounding factor in our estimates. In our cross-sectional data we observe current financial literacy and information of credit counseling received within the previous 6 months. Credit counseling may improve (or possibly worsen) financial literacy, in which case our estimate of the relationship between financial literacy and credit counseling would be biased upwards. 
Table 5. Credit counseling baseline and selectivity correction models

\begin{tabular}{|c|c|c|c|c|c|c|}
\hline & \multicolumn{2}{|l|}{ (1) } & \multicolumn{3}{|c|}{ (2) } & (3) \\
\hline & \multirow{2}{*}{\multicolumn{2}{|c|}{$\begin{array}{l}\text { Baseline probit no } \\
\text { instruments }\end{array}$}} & \multicolumn{4}{|c|}{ Selectivity correction model } \\
\hline & & & \multicolumn{2}{|c|}{ First stage } & \multicolumn{2}{|c|}{ Second stage } \\
\hline & $\beta / \mathrm{SE}$ & Margin & $\beta / \mathrm{SE}$ & Margin & $\beta / \mathrm{SE}$ & Margin \\
\hline Literacy score $(0-4)$ & $-0.232 * * *(0.051)$ & $-0.043 * * *$ & $-0.075(0.040)$ & -0.024 & $-0.214 * *(0.071)$ & $-0.065^{* *}$ \\
\hline $\begin{array}{l}\text { Shocks: instruments in model (2) } \\
\text { Employment shock }(=1) \\
\text { Income shock }(=1) \\
\text { Health shock }(=1)\end{array}$ & & & $\begin{array}{l}0.247(0.148) \\
0.290 * *(0.094) \\
0.992 * * *(0.234)\end{array}$ & $\begin{array}{l}0.080 \\
0.095^{* *} \\
0.323^{* * *}\end{array}$ & & \\
\hline $\begin{array}{l}\text { Age } \\
18-24 \\
25-34 \\
35-44 \\
45-54\end{array}$ & $\begin{array}{l}-1.133 * * *(0.278) \\
-0.481 * *(0.164) \\
-0.407 *(0.164) \\
-0.189(0.150)\end{array}$ & $\begin{array}{l}-0.211^{* * *} \\
-0.089^{* *} \\
-0.076^{*} \\
-0.035\end{array}$ & $\begin{array}{r}-0.356(0.187) \\
-0.090(0.134) \\
-0.084(0.132) \\
0.053(0.122)\end{array}$ & $\begin{array}{r}-0.116 \\
-0.029 \\
-0.027 \\
0.017\end{array}$ & $\begin{array}{l}-1.023 * *(0.400) \\
-0.704 * *(0.248) \\
-0.405(0.238) \\
-0.208(0.213)\end{array}$ & $\begin{array}{l}-0.313^{* *} \\
-0.215^{* *} \\
-0.124 \\
-0.064\end{array}$ \\
\hline $\begin{array}{l}\text { Housing } \\
\text { Homeowner without } \\
\text { mortgage }(=1)\end{array}$ & $-0.928 * * *(0.206)$ & $-0.172 * * *$ & $-0.637 * * *(0.148)$ & $-0.207 * * *$ & $-1.257 * *(0.430)$ & $-0.384 * *$ \\
\hline $\begin{array}{l}\text { Homeowner with mortgage } \\
(=1)\end{array}$ & $-0.399 * *(0.145)$ & $-0.074 * *$ & $-0.431^{* * *}(0.120)$ & $-0.140^{* * *}$ & $-0.112(0.221)$ & -0.034 \\
\hline Household finances & & & & & & \\
\hline $\begin{array}{l}\text { Household income (£10,000s) } \\
\text { Household income }{ }^{2} \\
\text { Consumer credit debt }(£ 1,000 s)\end{array}$ & $\begin{array}{l}-0.231 * *(0.078) \\
0.015 *(0.007) \\
0.031 * *(0.006)\end{array}$ & $\begin{array}{l}-0.043^{* *} \\
0.003^{*} \\
0.006^{* * *}\end{array}$ & $\begin{array}{c}-0.261 * * *(0.060) \\
0.014 * *(0.005) \\
0.032 * * *(0.006)\end{array}$ & $\begin{array}{c}-0.085^{* * *} \\
0.005^{* *} \\
0.010^{* * *}\end{array}$ & $\begin{array}{r}-0.190(0.127) \\
0.014(0.010) \\
0.016(0.011)\end{array}$ & $\begin{array}{r}-0.058 \\
0.004 \\
0.005\end{array}$ \\
\hline
\end{tabular}




$\begin{array}{lccc}\text { Observations (censored) } & 1,268 & 1,268 & 1,268(819) \\ \text { Baseline predicted probability } & 0.128 & 0.354 & 0.211 \\ \text { LR } \chi^{2} / \text { Wald } \chi^{2} & 112.598 & 193.260 & 34.254 \\ \text { Wald test of independence } & & 0.034\end{array}$

$* \mathrm{p}<0.05 ; * * \mathrm{p}<0.01 ; * * * \mathrm{p}<0.001$. Standard errors in parentheses.

Omitted variables: age: 55+; housing: renters. Further controls for gender, marital status, (spouse) employment status, dependent children and outstanding secured credit.

Note: Table shows results from probit and Heckman selection correction models in which the dependent variable is a $1 / 0$ dummy variable indicating whether the respondent sought credit counseling from a professional advisor in the previous 6 months. Column 1 presents results from a probit model without instruments. Columns 2 and 3 present results from a probit model with sample correction in which the selection equation instruments the likelihood of the respondent having a 'debt problem' (which may be endogenous to financial literacy), using shocks to the household as instruments. Source: YouGov Debt Tracker, October 2010. 
The second part of our estimation strategy addresses this potential reverse causality between credit counseling and financial literacy by incorporating an IV model for financial literacy. The previous literature on financial literacy has used alternative instruments for current financial literacy, including parental background (van Rooij et al., 2011), mathematical ability (Jappelli and Padula, 2013) when young, and previous experience of education in economics and finance (Bernheim et al., 2001; Lusardi and Tufano, 2009).

We follow Lusardi and Tufano (2009) by instrumenting current financial literacy using responses to the question on economics and finance education at school described earlier. As Jappelli and Padula (2013) show, the ideal instrument for financial literacy is the pre-labor market entry endowment of literacy. This is determined before exposure to the financial environment which might cause literacy to form endogenously. In our scenario, it is important that the instrument captures literacy formed before exposure to problem debt and specifically credit counseling. Financial education when young is appropriate in this context as it pre-dates problem debt or credit counseling.

The model we estimate, therefore, combines a selectivity-correction in the assignment into debt problem on the basis of financial shocks with an instrumentation of current financial literacy using financial education when young. This is a hybrid of a Heckman selectivity correction model and an IV probit model and can be written as:

$$
\begin{gathered}
F L=\beta_{0}+\beta_{1} \text { education }+\beta_{2} I M R+\mathbf{X}^{\prime} \beta+\varepsilon, \\
\text { credit counseling }=1\left[\beta_{0}+\beta_{1} F L+\beta_{2} I M R+\mathbf{X}^{\prime} \beta+\mu>0\right],
\end{gathered}
$$

where education is the continuous level of financial education at school, which we use as an instrument for financial literacy. IMR is the 'Inverse Mills Ratio', which is the sample selection correction term of the Heckman procedure before. ${ }^{1}$ Hence, this hybrid approach is implemented by calculating the IMR from the selection equation (2) and including it as an additional covariate in an IV probit model (this approach is discussed in Ameniya, 1985). Equations (3) and (4) are then jointly estimated using maximum likelihood estimation.

Table 6 shows results from this hybrid model. The coefficient on the financial education instrument in the first-stage regression in Column 1 is positive and statistically significant at the $0.1 \%$ level. The coefficient value of 0.152 implies a one unit increase in the instrument value (on the scale 'hardly at all', 'a little', 'some' and 'a lot') causes a 0.15 unit increase in the financial literacy score. In the second-stage regression, the coefficient on the instrumented financial literacy score is negative and statistically significant at the $0.1 \%$ level of confidence. The coefficient on the literacy score is -0.306 , compared with -0.065 in the selectivity correction model in Table 4 . This confirms our intuition that not instrumenting the financial literacy score causes an upward bias on this coefficient arising from the reverse causality between credit counseling and financial literacy. The coefficient value of -0.306 implies a one unit increase

1 The IMR or 'hazard rate' is the ratio of the probability density function and the cumulative distribution function evaluated at the predicted outcomes of (2), divided by the standard error of (2). 
Table 6. Credit counseling selectivity correction specification with additional instrument for financial literacy

(1)

(2)

Selectivity correction model with IV financial literacy

\begin{tabular}{|c|c|c|}
\hline First stage & \multicolumn{2}{|c|}{ Second stage } \\
\hline$\beta / \mathrm{SE}$ & $\beta / \mathrm{SE}$ & Margin \\
\hline
\end{tabular}

\begin{tabular}{|c|c|c|c|}
\hline \multicolumn{2}{|c|}{ Instrumented variable } & $-1.141 * * *(0.027)$ & $-0.306^{* * *}$ \\
\hline \multicolumn{4}{|l|}{ Instruments } \\
\hline Financial education in school (1-4) & $0.152 * * *(0.030)$ & & \\
\hline Inverse Mills Ratio & $1.963 * * *(0.150)$ & $2.124 * * *(0.254)$ & $0.570 * * *$ \\
\hline \multicolumn{4}{|l|}{ Age } \\
\hline $18-24$ & $-0.729 * * *(0.127)$ & $-0.852 * * *(0.238)$ & $-0.229 * * *$ \\
\hline $25-34$ & $-0.317 * * *(0.089)$ & $-0.359 * *(0.127)$ & $-0.096^{* *}$ \\
\hline $35-44$ & $-0.212 *(0.090)$ & $-0.254 *(0.120)$ & $-0.068 *$ \\
\hline $45-54$ & $-0.006(0.080)$ & $-0.016(0.098)$ & -0.004 \\
\hline \multicolumn{4}{|l|}{ Housing } \\
\hline Homeowner without mortgage $(=1)$ & $-0.662 * * *(0.126)$ & $-0.819 * * *(0.182)$ & $-0.220 * * *$ \\
\hline Homeowner with mortgage $(=1)$ & $-0.399 * * *(0.096)$ & $-0.480 * * *(0.110)$ & $-0.129 * * *$ \\
\hline \multicolumn{4}{|l|}{ Household finances } \\
\hline Household income $(£ 10,000 \mathrm{~s})$ & $-0.432 * * *(0.054)$ & $-0.485^{* * *}(0.059)$ & $-0.130^{* * *}$ \\
\hline Household income ${ }^{2}$ & $0.025^{* * *}(0.004)$ & $0.028 * * *(0.004)$ & $0.008^{* * *}$ \\
\hline Consumer credit debt $(£ 1,000 \mathrm{~s})$ & $0.048 * * *(0.005)$ & $0.055^{* * *}(0.006)$ & $0.015^{* * *}$ \\
\hline Observations & 1,268 & 1,268 & \\
\hline Baseline predicted probability & 1.754 & 0.461 & \\
\hline$F$-Statistic & 10.270 & & \\
\hline Wald test of independence & & 0.000 & \\
\hline
\end{tabular}

$* \mathrm{p}<0.05 ; * * \mathrm{p}<0.01 ; * * \mathrm{p}<0.001$. Standard errors in parentheses.

Omitted variables: age: 55+; housing: renters. Further controls for gender, marital status, (spouse) employment status, dependent children and outstanding secured credit.

Note: Table shows results from a selectivity correction model (as in previous Table 5), in which 'financial literacy' is also instrumented using 'financial education at school'. This is implemented by calculating the Inverse Mills Ratio from the selectivity correction model shown in Table 5, Columns 2 and 3 and then including it as an additional control variable in the twostage IV specification in order to implement the selectivity correction.

Source: YouGov Debt Tracker, October 2010.

in the financial literacy score lowers the likelihood of an individual seeking credit counseling by $31 \%$ points. Evaluated against a baseline likelihood of $46 \%$, this is a $66 \%$ decrease in the likelihood of seeking credit counseling.

The result from the hybrid model shows that financial literacy decreases the likelihood that, for a given debt problem, an individual seeks credit counseling. Hence financial literacy and credit counseling are substitutes in consumer decisions. Our data do not allow us to estimate whether financial literacy and credit counseling are substitutes in determining outcomes for individuals faced with problem debt - 
we do not know whether own financial literacy compared with credit counseling advice from an organization or agency are more or less effective for helping consumers address their debt and credit problems. Our results do allow us to conclude, however, that lack of financial literacy is not a barrier to seeking advice. Lack of financial literacy could potentially leave consumers unable to understand the appropriate form of assistance they require to help them address their debt problems. Our results show this ignorance hypothesis is not borne out in our data.

\section{Sensitivity analysis}

In this section, we present estimates from alternative model specifications to ensure that our central results are not sensitive to choice of exclusion restrictions in the selection equation or to our definition of 'debt problem'. Table A2 presents model estimates in which we omit the income and employment shock variables as exclusion restrictions. Hence, the single exclusion restriction in this model arises from the health shock variable. We do so as arguably income and employment shocks might arise due to poor financial literacy, whereas it would seem highly unlikely that health shocks could arise due to poor financial literacy. In this specification, the coefficient on the health shock dummy variable is statistically significant at the $0.1 \%$ level, and the coefficient and standard error values are very similar to our model in Table 5 (coefficient 1.111, standard error 0.367). Results in Column 2 show the IMR remains significant in the second-stage regression and the marginal effect on the instrumented financial literacy score variable of 0.328 is very close to the value of 0.306 in our central model (Column 2, Table 6).

We also present model estimates using alternative definitions of 'debt problem' explained earlier. Table A3 presents results in which 'debt problem' is defined using the narrower definition of stating answers 4 or 5 to the survey question on ability to repay bills and credit commitments as shown in Table 3 earlier. By this narrow definition only $9 \%$ of our sample is classed as exhibiting a problem debt compared with $35 \%$ for the wider definition in the central estimates. Table A3 shows results are very similar to our central estimates. In these results, the coefficient on the literacy score variable is again negative and statistically significant at the $0.1 \%$ level of confidence. The average marginal effect value of -0.294 is very similar to the equivalent value of -0.306 from the previous hybrid model in Table 6 . The baseline predicted probability from this model is $47 \%$, hence a one unit increase in the literacy score causes a $63 \%$ reduction in the likelihood of seeking credit counseling, near identical to the $66 \%$ reduction from the previous model.

Table A4 presents results using our third definition of debt problem based on whether the survey respondent states their financial situation is worse than 12 months previously. $14 \%$ of individuals report this to be the case and are coded into the debt problem group for the estimates as shown in this table. Arguably, individuals who persistently report they face problems repaying their credit commitments and bills may exhibit long-term lack of income or poverty for which credit counseling may not be appropriate. The new measure might better capture transitory events which may be more readily addressed via credit counseling. 
In these results, the coefficient in the second-stage regression estimates is very similar to those in the previous two models. The coefficient on the instrumented financial literacy score is negative and statistically significant at the $0.1 \%$ level. The coefficient value of 0.299 implies a one unit increase in financial literacy lowers the likelihood of seeking credit counseling by $64 \%$. Taken together, results from these sensitivity checks show the estimated coefficients of interest are not sensitive to the choice of shock variables in the selection equation or alternative definitions of 'debt problem' in the first-stage selection equation.

\section{Conclusion}

This paper has estimated the impact of financial literacy on the demand for professional 'credit counseling' among consumers facing financial problems. It used a unique UK survey dataset of indebted individuals into which we inserted survey questions on financial literacy and other behavioral characteristics of consumers. It allowed for both the endogeneity of an individual's debt problems to financial literacy, and the endogeneity of financial literacy to exposure to credit counseling, and showed that, for a given debt problem, financial literacy decreased the likelihood of an individual seeking help and assistance from a credit counselor by approximately $60 \%$. This result supports the view that credit counseling is a substitute, and maybe a safety net, for poor financial literacy. We subject this view to various sensitivity analyses which confirm the robustness of this conclusion.

What are the policy implications of our findings? We confirm the findings in the existing literature that levels of financial literacy are strongly linked to prior financial education, and, indirectly, that financial literacy may have an impact on financial decision-making. However, prior financial knowledge may not of itself be sufficient to avoid households encountering debt problems arising from exogenous shocks to household circumstances, such as health shocks and income shocks. The latter are particularly pertinent in the post-2007 period of macroeconomic instability; a period covered by our data. Hence there is a social need for further provision of financial advice, such as credit counseling, that is triggered by adverse shocks to the household. The issue that concerns us here is whether such advice is essentially complementary to, or a substitute for, accrued financial literacy among individuals. Arguably, the 'value added' of such advice is the greatest to those with the least financial expertize (indeed, if it was complementary to existing knowledge, one might question the usefulness of that accrued financial literacy). Our results strongly suggest that credit counseling is utilized disproportionately by those with less financial literacy, acting as a valuable 'safety net' in the context of household debt problems.

Much of the existing literature that has focused on pre-determined drivers of financial literacy, such as financial education, and has concentrated on active financial decisions that are taken by households, such as saving choices. Rather less attention has been paid to actions of households consequent upon adverse shocks to the household. Moreover, the average effects of interventions such as early-life financial education conceal variations in outcomes in terms of financial literacy. Credit counseling therefore serves as an important and distinct component of financial advice, not 
only because it is an explicit response to adverse outcomes such as debt problems, but also because of its potential back-up function for the less financially literate, whether or not such individuals have received prior financial education. Showing, as we do here, that credit counseling is a substitute for financial literacy, does not suggest that measures to increase the latter are not cost effective, but it does suggest that emphasis on financial education at the expense of safety net mechanisms in the presence of adverse shocks to households could be overstated given the likelihood of continued variation in levels of financial literacy across households.

\section{References}

Agarwal, S., Amromin, G., Ben-David, I., Chomsisengphet, S. and Evanoff, D. D. (2014) The effectiveness of mandatory mortgage counseling: can one dissuade borrowers from choosing risky mortgages? NBER Working Paper, No. 19920.

Amemiya, T. (1985) Advanced Econometrics. Cambridge, MA: Harvard University Press.

Behrman, J. R., Mitchell, O. S., Soo, C. K. and Bravo, D. (2012) How financial literacy affects household wealth accumulation. American Economic Review, 102(3): 300-304.

Bernheim, B. (1995) Do households appreciate their financial vulnerabilities? An analysis of actions, perceptions, and public policy. In Tax Policy and Economic Growth. Washington, DC: American Council for Capital Formation, pp. 1-30.

Bernheim, B. (1998) Financial illiteracy, education, and retirement saving. In Mitchell, O. S. and Schieber, S. J. (eds), Living with Defined Contribution Pensions. Philadelphia: University of Pennsylvania Press, pp. 36-68.

Bernheim, B. D., Garrett, D. M. and Maki, D. M. (2001) Education and saving: the long-term effects of high school financial curriculum mandates. Journal of Public Economics, 80: 435-465.

Bucher-Koenen, T. and Koenen, J. (2015) Do seemingly smarter consumers get better advice? MEA Discussion Paper, 01-2015.

Calcagno, R. and Monticone, C. (2015) Financial literacy and the demand for financial advice. Journal of Banking and Finance, 50: 363-380.

Carpena, F., Cole, S., Shapiro, J. and Zia, B. (2011) Unpacking the causal chain of financial literacy. World Bank Policy Research Working Paper, 5798.

Chan, S. and Stevens, A. H. (2008) What you don't know can't help you: pension knowledge and retirement decision-making. Review of Economics and Statistics, 90(2): 253-266.

Christelis, D., Jappelli, T. and Padula, M. (2010) Cognitive abilities and portfolio choice. European Economic Review, 54(1): 18-38.

Cole, S., Sampson, T. and Zia, B. (2011) Prices or knowledge? what drives demand for financial services in emerging markets? Journal of Finance, 66: 1933-1967.

Collins, J. (2012) Financial advice: a substitute for financial literacy? Financial Services Review, 21(4): 307-322.

Disney, R. and Gathergood, J. (2013) Financial literacy and consumer credit portfolios. Journal of Banking and Finance, 37(7): 2246-2254.

Elliehausen, G., Christopher Lundquist, E. and Staten, M. E. (2007) The impact of credit counseling on subsequent borrower behavior. Journal of Consumer Affairs, 41(1): 1-28.

Gathergood, J. (2012) Self-control, financial literacy and consumer over-indebtedness. Journal of Economic Psychology, 33(3): 590-602.

Gathergood, J. and Weber, J. (2014) Self-control, financial literacy and the co-holding puzzle. Journal of Economic Behavior and Organization, 107(Part B): 455-469.

Gerardi, K., Goette, L. and Meier, S. (2013) Numerical ability predicts mortgage default. Proceedings of the National Academy of Sciences of the United States of America, 110(28): 11, 267-71. 
Hackethal, A., Haliassos, M. and Jappelli, T. (2012) Financial advisors: a case of babysitters? Journal of Banking and Finance, 36(2): 509-524.

Jappelli, T. (2010) Economic literacy: an international comparison. Economic Journal, 120 (548): 429-451.

Jappelli, T. and Padula, M. (2013) Investment in financial literacy and saving decisions. Journal of Banking and Finance, 37(8): 2779-2792.

Lusardi, A. and Mitchell, O. S. (2007) Baby Boomer retirement security: the roles of planning, financial literacy, and housing wealth. Journal of Monetary Economics, 54(1): 205-224.

Lusardi, A. and Mitchell, O.S. (2011) Financial literacy around the world: an overview. Journal of Pension Economics and Finance, 10(4): 497-508.

Lusardi, A. and Mitchell, O. S. (2014) The economic importance of financial literacy: theory and evidence. Journal of Economic Literature, 52: 5-44.

Lusardi, A. and Tufano, P. (2009) Debt literacy, financial experiences, and overindebtedness. NBER Working Paper, 14808.

Money Advice Service (2013) Debt advice services in the UK: a snapshot of demand and supply. Technical Report (September).

Moulton, S., Loibl, C., Samak, A. and Collins, J. M. (2013) Borrowing capacity and financial decisions of low-to-moderate income first-time homebuyers. Journal of Consumer Affairs, 47 (3): $375-403$.

Nurcan, N. A. and Bièáková, A. (2010) Self-control and debt: evidence from data on credit counselling. University of Oxford, Discussion Paper Series, 504.

Staten, M. E. (2006) The evolution of the credit counseling industry. In Giuseppe, B., Disney, R. and Grant, C. (eds), The Economics of Consumer Credit. Cambridge: MIT Press, pp. 275-300.

van Rooij, M. C., Lusardi, A. and Alessie, R. J. (2011) Financial literacy and stock market participation. Journal of Financial Economics, 101(2): 449-472.

Willis, L.E. (2011) The financial education fallacy. American Economic Review, 101(3): 429-434.

Xiao, J. J., Sorhaindo, B. and Garman, E. T. (2006) Financial behaviours of consumers in credit counselling. International Journal of Consumer Studies, 30: 108-121.

Yoong, J. (2011) Financial illiteracy and stock market participation: evidence from the RAND American life panel. In Olivia, S. Mitchell and Lusardi, A. (eds), Financial Literacy: Implications for Retirement Security and the Financial Marketplace. Oxford and New York: Oxford University Press, pp. 76-97. 
Table A1. Determinants of financial literacy

\begin{tabular}{|c|c|c|c|c|c|}
\hline & (1) & (2) & (3) & (4) & (5) \\
\hline & $\begin{array}{c}\text { Ordered probit } \\
\qquad \beta / \mathrm{SE}\end{array}$ & $\begin{array}{c}\text { Literacy }=0 \\
\text { margins }\end{array}$ & $\begin{array}{c}\text { Literacy }=1 \\
\text { margins }\end{array}$ & $\begin{array}{c}\text { Literacy }=2 \\
\text { margins }\end{array}$ & $\begin{array}{l}\text { Literacy }=3 \\
\text { margins }\end{array}$ \\
\hline \multicolumn{6}{|l|}{ Age } \\
\hline $18-24$ & $-0.289 *(0.143)$ & $0.046^{*}$ & $0.064 *$ & -0.016 & $-0.094^{*}$ \\
\hline $25-34$ & $-0.238 *(0.099)$ & $0.038 *$ & $0.053^{*}$ & $-0.013^{*}$ & $-0.078^{*}$ \\
\hline $35-44$ & $-0.068(0.102)$ & 0.011 & 0.015 & -0.004 & -0.022 \\
\hline $45-54$ & $-0.063(0.095)$ & 0.010 & 0.014 & -0.004 & -0.021 \\
\hline \multicolumn{6}{|l|}{ Demographics } \\
\hline Male $(=1)$ & $0.201 *(0.064)$ & $-0.032 * *$ & $-0.045^{* *}$ & $0.011 * *$ & $0.066^{* *}$ \\
\hline $\begin{array}{l}\text { Married/living as } \\
\text { married }(=1)\end{array}$ & $-0.007(0.118)$ & 0.001 & 0.002 & -0.000 & -0.002 \\
\hline $\begin{array}{l}\text { Financial education } \\
\text { in school }(1-4)\end{array}$ & $0.181 * * *(0.036)$ & $-0.029 * * *$ & $-0.040^{* * *}$ & $0.010 * * *$ & $0.059^{* * *}$ \\
\hline \multicolumn{6}{|l|}{ Employment } \\
\hline Employed (=1) & $0.088(0.080)$ & -0.014 & -0.020 & 0.005 & 0.029 \\
\hline Unemployed (=1) & $0.308 *(0.149)$ & $-0.049 *$ & $-0.069 *$ & $0.017 *$ & $0.101^{*}$ \\
\hline \multicolumn{6}{|l|}{ Household finances } \\
\hline $\begin{array}{l}\text { Household income } \\
(£ 10,000 \text { s })\end{array}$ & $-0.034(0.049)$ & 0.005 & 0.008 & -0.002 & -0.011 \\
\hline Household income ${ }^{2}$ & $0.005(0.004)$ & -0.001 & -0.001 & 0.000 & 0.001 \\
\hline \multicolumn{6}{|l|}{ Shocks to the houshold } \\
\hline $\begin{array}{l}\text { Employment } \\
\text { shock }(=1)\end{array}$ & $-0.091(0.120)$ & 0.015 & 0.020 & -0.005 & -0.030 \\
\hline Income shock $(=1)$ & $-0.003(0.076)$ & 0.001 & 0.001 & -0.000 & -0.001 \\
\hline Health shock $(=1)$ & $-0.210(0.171)$ & 0.034 & 0.047 & -0.012 & -0.069 \\
\hline Observations & 1,268 & & & & \\
\hline $\operatorname{LR} \chi^{2}$ & 61.541 & & & & \\
\hline Prob $>\chi^{2}$ & 0.000 & & & & \\
\hline $\begin{array}{l}\text { Baseline predicted } \\
\text { probability }\end{array}$ & 1.754 & & & & \\
\hline
\end{tabular}

$* \mathrm{p}<0.05 ; * * \mathrm{p}<0.01 ; * * \mathrm{p}<0.001$. Standard errors in parentheses.

Omitted variables: age: $55+$. Further controls for spouse employment status, dependent children and being divorced.

Note: Table shows the results from an Ordered Probit model in which the dependent variable is the financial literacy score (number of financial literacy questions answered correctly on a scale of $0-3$. Financial education in school is the self-reported extent of education in finance and/or economics during compulsory schooling (for full question see main text).

Source: YouGov Debt Tracker, October 2010. 
Table A2. Robustness analysis: health shock is single instrument for selectivity correction with IV financial literacy estimates

(1)

(2)

Selectivity correction model with IV financial literacy

\begin{tabular}{clc}
\hline First stage & \multicolumn{2}{c}{ Second stage } \\
\hline$\beta / \mathrm{SE}$ & $\beta / \mathrm{SE}$ & Margin \\
\hline
\end{tabular}

Instrumented variable

Literacy score $(0-4)$

$-1.177^{* * *}(0.058) \quad-0.328^{* * *}$

Instruments

Financial education in

school (1-4)

Inverse Mills Ratio

Age

$18-24$

25-34

$35-44$

$45-54$

$0.136^{* * *}(0.029)$

$3.351^{* * *}(0.183)$

$4.018^{* * *}(0.273)$

$1.121^{* * *}$

Housing

Homeowner without

$-1.081^{* * *}(0.142) \quad-1.176^{* * *}(0.262) \quad-0.328^{* * *}$

$-0.415^{* * *}(0.089) \quad-0.436^{* *}(0.136)-0.122^{* *}$

$-0.337 * * *(0.089) \quad-0.366^{* *}(0.126) \quad-0.102^{* *}$

$0.004(0.076) \quad-0.025(0.098) \quad-0.007$

mortgage $(=1)$

Homeowner with mortgage $(=1)$

Household finances

Household income $(£ 10,000 \mathrm{~s})$

Household income ${ }^{2}$

$-1.230 * * *(0.185)$

$-1.448 * * *(0.204) \quad-0.404 * * *$

Consumer credit debt $(£ 1,000 \mathrm{~s})$

$-0.767^{* * *}(0.128)$

$-0.916^{* * *}(0.120) \quad-0.256^{* * *}$

$-0.692 * * *(0.083)$

$-0.812 * * *(0.068) \quad-0.227 * * *$

$0.039 * * *(0.005)$

$0.046 * * *(0.005) \quad 0.013 * * *$

$0.077 * * *(0.009)$

$0.090 * * *(0.008)$

$0.025^{* * *}$

\begin{tabular}{lll}
\hline Observations & 1,268 & 1,268 \\
Baseline predicted probability & 1.754 & 0.478 \\
$F$-Statistic & 8.867 & \\
Wald test of independence & & 0.000 \\
\hline
\end{tabular}

${ }^{*} \mathrm{p}<0.05 ; * * \mathrm{p}<0.01 ; * * * \mathrm{p}<0.001$. Standard errors in parentheses

Omitted variables: age: 55+; housing: renters. Further controls for gender, marital status, (spouse) employment status, dependent children and outstanding secured credit.

Note: Table shows results from a robustness specification of the selectivity correction model with instrumentation as in Table 6 . Here, the selectivity correction model uses only an experienced health shock as instrument.

Source: YouGov Debt Tracker, October 2010. 
Table A3. Robustness analysis: narrower definition of 'debt problems', selectivity correction with IV financial literacy estimates

(1)

(2)

\begin{tabular}{|c|c|c|c|}
\hline & \multirow{2}{*}{\multicolumn{3}{|c|}{ Selectivity correction model with IV financial literacy }} \\
\hline & & & \\
\hline & \multirow{2}{*}{$\begin{array}{c}\text { First stage } \\
\beta / \mathrm{SE}\end{array}$} & \multicolumn{2}{|c|}{ Second stage } \\
\hline & & $\beta / \mathrm{SE}$ & Margin \\
\hline \multicolumn{4}{|l|}{ Instrumented variable } \\
\hline Literacy score $(0-4)$ & & $-1.104 * * *(0.030)$ & $-0.294 * * *$ \\
\hline \multicolumn{4}{|l|}{ Instruments } \\
\hline $\begin{array}{l}\text { Financial education in } \\
\text { school }(1-4)\end{array}$ & $0.159 * * *(0.030)$ & & \\
\hline Inverse Mills Ratio & $0.979 * * *(0.110)$ & $1.012 * * *(0.172)$ & $0.270 * * *$ \\
\hline \multicolumn{4}{|l|}{ Age } \\
\hline $18-24$ & $-0.520 * * *(0.128)$ & $-0.582 *(0.243)$ & $-0.155^{*}$ \\
\hline $25-34$ & $-0.504 * * *(0.097)$ & $-0.529 * * *(0.120)$ & $-0.141 * * *$ \\
\hline $35-44$ & $-0.159(0.093)$ & $-0.183(0.120)$ & -0.049 \\
\hline $45-54$ & $-0.168 *(0.084)$ & $-0.180(0.094)$ & -0.048 \\
\hline \multicolumn{4}{|l|}{ Housing } \\
\hline $\begin{array}{l}\text { Homeowner without } \\
\text { mortgage }(=1)\end{array}$ & $-0.776^{* * *}(0.153)$ & $-0.878 * * *(0.182)$ & $-0.234^{* * *}$ \\
\hline Homeowner with mortgage $(=1)$ & $-0.173(0.092)$ & $-0.214(0.110)$ & -0.057 \\
\hline \multicolumn{4}{|l|}{ Household finances } \\
\hline Household income (£10,000s) & $-0.286^{* * *}(0.049)$ & $-0.306^{* * *}(0.057)$ & $-0.082 * * *$ \\
\hline Household income $^{2}$ & $0.021 * * *(0.004)$ & $0.023^{* * *}(0.005)$ & $0.006^{* * *}$ \\
\hline Consumer credit debt $(£ 1,000 \mathrm{~s})$ & $0.032 * * *(0.005)$ & $0.035 * * *(0.006)$ & $0.009 * * *$ \\
\hline Observations & 1,268 & 1,268 & \\
\hline Baseline predicted probability & 1.754 & 0.465 & \\
\hline$F$-Statistic & 7.428 & & \\
\hline Wald test of independence & & 0.000 & \\
\hline
\end{tabular}

$* \mathrm{p}<0.05 ; * \mathrm{p}<0.011 * * * \mathrm{p}<0.001$. Standard errors in parentheses

Omitted variables: age: 55+; housing: renters. Further controls for gender, marital status, (spouse) employment status, dependent children and outstanding secured credit.

Note: Table shows results from a robustness specification of the selectivity correction model with instrumentation (Table 6). Here, the dependent variable is our narrower definition of debt problems: a dummy variable whether subjects answer 'falling behind with commitments' or 'real financial problems' to their debt problem characteristics (Table 3).

Source: YouGov Debt Tracker, October 2010. 
Table A4. Robustness analysis: alternative definition of 'debt problems', selectivity correction with IV financial literacy estimates

(1)

(2)

Selectivity correction model with IV financial literacy

\begin{tabular}{clc}
\hline First stage & \multicolumn{2}{c}{ Second stage } \\
\hline$\beta / \mathrm{SE}$ & $\beta / \mathrm{SE}$ & Margin \\
\hline
\end{tabular}

\begin{tabular}{|c|c|c|c|}
\hline Literacy score $(0-4)$ & & $-1.108 * * *(0.036)$ & $-0.299^{* * *}$ \\
\hline \multicolumn{4}{|l|}{ Instruments } \\
\hline $\begin{array}{l}\text { Financial education in school } \\
(1-4)\end{array}$ & $0.158^{* * *}(0.030)$ & & \\
\hline Inverse Mills Ratio & $0.900 * * *(0.100)$ & $0.948^{* * *}(0.138)$ & $0.253 * * *$ \\
\hline \multicolumn{4}{|l|}{ Age } \\
\hline $18-24$ & $-0.396 * *(0.125)$ & $-0.452(0.261)$ & -0.120 \\
\hline $25-34$ & $-0.374 * * *(0.093)$ & $-0.398 * *(0.128)$ & $-0.106^{* *}$ \\
\hline $35-44$ & $0.044(0.092)$ & $0.030(0.134)$ & 0.008 \\
\hline $45-54$ & $-0.013(0.082)$ & $-0.020(0.098)$ & -0.005 \\
\hline \multicolumn{4}{|l|}{ Housing } \\
\hline $\begin{array}{l}\text { Homeowner without } \\
\text { mortgage }(=1)\end{array}$ & $-0.216(0.112)$ & $-0.306(0.204)$ & -0.082 \\
\hline Homeowner with mortgage $(=1)$ & $-0.046(0.087)$ & $-0.085(0.118)$ & -0.023 \\
\hline \multicolumn{4}{|l|}{ Household finances } \\
\hline Household income (£10,000s) & $-0.214 * * *(0.044)$ & $-0.235^{* * *}(0.060)$ & $-0.063^{* * *}$ \\
\hline Household income ${ }^{2}$ & $0.013 * * *(0.003)$ & $0.014 * *(0.005)$ & $0.004^{* *}$ \\
\hline Consumer credit debt $(£ 1,000 \mathrm{~s})$ & $0.031 * * *(0.005)$ & $0.035^{* * *}(0.007)$ & $0.009 * * *$ \\
\hline Observations & 1,268 & 1,268 & \\
\hline Baseline predicted probability & 1.754 & 0.467 & \\
\hline$F$-Statistic & 8.320 & & \\
\hline Wald test of independence & & 0.000 & \\
\hline
\end{tabular}

${ }^{*} \mathrm{p}<0.05 ; * * \mathrm{p}<0.01 ; * * * \mathrm{p}<0.001$. Standard errors in parentheses.

Omitted variables: age: 55+; housing: renters. Further controls for gender, marital status, (spouse) employment status, dependent children and outstanding secured credit.

Note: Table shows results from a robustness specification of the selectivity correction model with instrumentation (Table 6). Here, the dependent variable is a dummy variable for answers to the question 'Is your financial situation worse than it was 12 months ago?' The variable takes a value of 1 if the respondent answered 'yes' and 0 otherwise.

Source: YouGov Debt Tracker, October 2010. 